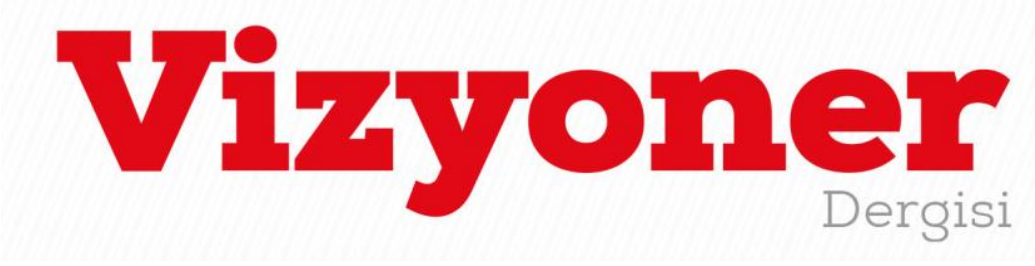

Süleyman Demirel Üniversitesi Vizyoner Dergisi, Yıl: 2020, Cilt: 11, Sayı: 27, 555-572.

Süleyman Demirel University Visionary Journal, Year: 2020, Volume: 11, No: 27, 555-572.

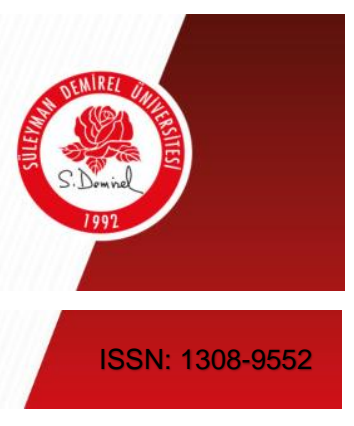

ARAŞTIRMA MAKALESİ / RESEARCH ARTICLE

\title{
BİR İŞTEN ÇIKARMA SEBEBİ OLARAK SOSYAL MEDYA: ÖRNEK OLAY ÇALIŞMASI
}

\section{SOCIAL MEDIA AS A REASON FOR DISMISSAL: A CASE STUDY}

\section{Fatma Zehra YILDIZ ${ }^{1}$}

Arş. Gör. Dr. Derya Gül ÖZTÜRK²

\begin{abstract}
ÖZ
Küçülme, performans ya da davranış gibi çeşitli sebeplerle ortaya çıkan işten çıkarma uygulamaları, çalışma yaşamında önemli bir yere sahiptir. Gelişen teknoloji ve insanların her an her yerde ulaşabildikleri sosyal medya araçlarının yaygınlaşmasıyla birlikte işten çıkarma sebepleri de değişmiştir. Bu araştırmanın amacı, çalışanların sosyal medya paylaşımlarının işten çıkarma sebebi oluşturup oluşturmayacağını incelemektir. Çalışanların yaptıkları sosyal medya paylaşımları, işten çıkarma ve mahremiyet bağlamında değerlendirilmiştir. Araştırmada nitel araştırma türlerinden örnek olay yöntemi kullanılarak işten çıkarma ve sosyal medya olgularını temsil niteliği taşıyan örnekler derinlemesine incelenmiştir. Araştırma sonucunda, çalışanların mahremiyeti göz ardı ederek sosyal medya platformlarında yaptıkları paylaşımların işten çıkarma sebebi olabileceği görülmüştür. Nitekim çalışanın raporlu olduğu günde sosyal medyada plajdan tatil fotoğrafı paylaşmasının, sosyal medyada insan kaynaklarını hedef alarak sataşma niteliğinde söylemde bulunmasının, iş sözleşmesini kölelik sözleşmesi olarak nitelendirmesinin ve işyerinden kurumun logosunun göründüğü iş disiplinini bozan fotoğraf paylaşmasının işten çıkarma sebebi olabileceği ortaya çıkmıştır. Çalışmanın en önemli katkısı, sosyal medya sebebiyle işten çıkarma olgusunu mahremiyete yönelik modern tehditler olan ifşa ve gözetim bağlamında incelemesidir. Artık sosyal medya sadece işe alımda değil işten çıkarmada da işverenler için değerlendirme unsuru haline dönüşmüştür.
\end{abstract}

Anahtar Kelimeler: Sosyal Medya, Mahremiyet, İşten Çıkarma, İfşa, Gözetim.

JEL Sınıflandırma Kodları: K31, M12, K29, M19.

\begin{abstract}
The dismissal resulting from various reasons such as downsizing, performance or behaviour is an integral part of working life. With advancing technology and the common usage of social media tools that people can access anywhere, the reasons for dismissal have changed. The purpose of the study is to determine whether employees' social media posts is a cause of dismissal. Social media posts of employees are evaluated in the context of dismissal and privacy. In the research, examples which are the representative of dismissal and social media phenomena are examined in depth using the case study method, which is among the qualitative research types. As a result of the research, it is seen that the employees' posts on social media platforms could be the reason of dismissal. It is also revealed that sharing the holiday photo from the beach on social media when the employee is on sick leave, insulting human resources management from social media, describing the labour contract as a contract of slavery, sharing photos from workplace which includes logo of the institution that disrupts the business discipline may be the reason for dismissal. The most important contribution of the study is to examine the dismissal phenomenon
\end{abstract}

ID İstanbul Üniversitesi, Sosyal Bilimler Enstitüsü, İnsan Kaynakları Yönetimi Anabilim Dalı, zehrayldz07@gmail.com

2 (D) Aydın Adnan Menderes Üniversitesi, Söke İşletme Fakültesi, İnsan Kaynakları Yönetimi Bölümü, derya.gul@adu.edu.tr

Makale Geliş Tarihi / Received : : 31.12 .2019

Makale Kabul Tarihi / Accepted : : 06.04.2020 
due to social media in the context of self- exposure and surveillance, which are modern threats to privacy. Now, social media has become an evaluation factor for employers not only in recruitment but also in dismissal.

Keywords: Social Media, Privacy, Dismissal, Self-Exposure, Surveillance.

JEL Classification Codes: K31, M12, K29, M19.

\section{GİRIŞ}

İnsanlık tarihi boyunca yaşanan değişim ve gelişmeler tarım ve sanayi toplumlarının ardından günümüzdeki bilgi toplumunun oluşmasına neden olmuştur (Çelik, 1998: 3). Bilginin en değerli meta olduğu bilgi toplumunda bireylerin yeni teknolojilere erişebilme ve bu teknolojileri kullanabilme imkânı bulmasıyla bilgi teknolojileri her alanda günlük yaşamın bir parçası haline gelmiştir. Bilgi teknolojileri aracılığıyla bilginin her an her yerde erişebilir olması bilginin hızlı üretimi ve tüketimine, bireylerin ve dolayısıyla toplumun siyasi, sosyal, kültürel ve ekonomik yapısında önemli değişimlere neden olmuştur (Selvi, 2012: 195; Alaca ve Yılmaz, 2016: 508). Yaşanan bu değişimlerle birlikte bilgi teknolojilerindeki gelişmeler bireylerin günlük hayatında yaşadıkları her anı zaman ve mekân sınırı tanımaksızın sosyal medya platformları aracılığıyla bir ize, bir etikete dönüştürmektedir. Sosyal medyanın hayatın her alanında ve anında insanların yaşamında olmasının sosyal ilişkilerin yanı sıra çalışma ilişkilerine de etkisi olmuştur. Günümüzde neredeyse herkesin birden fazla sosyal medya hesabına sahip olduğu iletişim ortamında bireyler çoğu zaman kendi kimlikleriyle yaşantılarını ifşa etmekte ve kendi kurguladıkları bu sanal dünyada özgürce hareket etmektedirler. Bireyler kendine özgü işlevlere sahip olan sosyal medya platformlarında kendi ihtiyaçları doğrultusunda üretici veya tüketici kimlikleriyle yer alarak farklı gündemlere göre farklı performanslar sergilemektedirler. Bireylerin kimi zaman göz önünde olma kimi zamanda beğenilme arzusuyla sosyal medya ortamında özellikle çalışma yaşamına ilişkin yaptığı paylaşımlar kısa veya uzun vadede bazı sorunlara neden olmaktadır. Yaşanan bu sorunlarda bireylerin herhangi bir mahremiyet kaygısı taşımaksızın yalnızca belirli doyumlar elde etme arzusuyla hareket etmeleri etkili olmaktadır. Sosyal medya platformlarında kolaylıkla istedikleri topluluğa dâhil olan kullanıcılar iş yerinde yaptıkları paylaşımlardan dolayı işten çıkarma gibi çeşitli disiplin uygulamaları ile karşı karşıya kalabilmektedir.

$\mathrm{Bu}$ çalışmada, işten çıkarma sebebi olarak çalışanların sosyal medya paylaşımları incelenmektedir. Buna bağlı olarak çalışanların mahremiyete yönelik tutumlarının sosyal medya paylaşımlarına etkisi belirlenerek bu etkinin işten çıkarma sürecindeki rolü Yargıtay kararlarına dayanan örnek olaylar aracılığıyla açıklanmıştır.

İlgili alandaki çeşitli çalışmalardan (Thornthwaite, 2017; Baybora, 2017) farklı olarak işten çıkarmanın hukuki boyutu mahremiyete yönelik modern tehditler olan gözetim ve ifşa konularıyla birlikte ele alınarak değerlendirilmiştir. Nitel araştırmanın sağladığı anlam derinliği ve içerik zenginliği ile inşa edilen çalışma sosyal medya sebebiyle işten çıkarmanın hangi yollarla gerçekleştiğini anlama ve keşfetme imkânı sunmaktadır. Bu çalışma ayrıca işletmelerde sosyal medya kullanımı ve bu kullanımın çalışanlara yaratacağı zararı görme ve kıyaslama imkânı sağlama noktasında katkıda bulunmaktadır. Buradan hareketle, çalışmanın ilk bölümünde işten çıkarma alanyazının yanı sıra sosyal medya ve mahremiyet konularına değinilmektedir. Son bölümde ise, örnek olay olarak belirlenen Yargıtay kararlarına ilişkin değerlendirmelere yer verilmektedir.

\section{LITERATÜR}

Bu kısımda işten çıkarma, sosyal medya ve mahremiyet konuları ifade edilmiştir.

\section{1. İşten Çıkarma}

"Birini işe alırken üç niteliğe bakarız: Dürüstlük, zekâ ve enerji. Eğer kişiler bunlardan ilkine sahip değilse, diğer iki özellik sizin sonunuzu getirir.” Warren Buffet (Özdemir, 2017).

İşletmeler işe alım süreçlerinde genel olarak kişi-iş uyumu veya örgüt uyumunu gözeten düşüncelerle hareket etmektedirler. Oysa yukarıdaki sözde de ifade edildiği üzere bazı durumlarda dürüst bir çalışana sahip olmanın diğer pek çok unsurun önüne geçtiği özellikle işten çıkarma kararlarında ortaya çıkmaktadır.

İnsan kaynakları yönetimi literatüründe "işten çıkarma” (dismissal) kavramı genel olarak disiplin işlevinin son aşaması olarak incelenmektedir. Bir çalışanın firma ile olan iş ilişkisinin gönülsüz olarak son bulması durumunu 
işten çıkarma olarak tanımlamak mümkündür. Dessler (2000) işten çıkarmanın yetersiz performans, kötü davranış, iş için gerekli yeteneklerin eksikliği ve değişen iş gerekleri olmak üzere temelde dört sebebi olduğunu vurgulamaktadır (Dessler, 2000: 378-379). Çalışma hayatının bir gerçeği olarak "işten çıkarma” olgusu, insana dayalı stratejilerin önem kazanmasıyla birlikte yeni ve doğru politikaların belirlenmesinin gerektiği bir alana dönüşmektedir. $\mathrm{Bu}$ politikalar arasında, işten çıkış mülakatı ve yeniden işe yerleştirme (outplacement) uygulamaları ön plana çıkarken bu uygulamaların da dikkatli bir şekilde planlanması ve işten çıkarılan çalışanla yüz yüze iletişim kurulmasının çok önemli olduğu bilinmektedir (Dessler, 2000: 382-383).

İşten çıkarma, kovma, görevden alma ya da yeniden işe yerleştirme çeşitli kavramlarla ifade edilen "birinin işine son verme" eylemi aslında insan kaynakları yönetiminin en zorlayıcı fonksiyonlarından birini oluşturmaktadır. Yapılan bir araştırmada, özellikle küçük işletmelerin çalışanları işten çıkarmada zorlandıklarını, \%78'nin ise bu zorlu görevden kaçınmak için düşük performanslı çalışanları işte tutmaya devam ettiklerini ortaya koymaktadır. Eyleme geçmeden önce işten çıkarma kararı üzerine uzun bir süre düşünülmelidir. Yetersiz performansa bağlı işten çıkarmalarda, "İKY tüm standart altındaki performansları belgelemiş ve çalışana bildirmiş midir?” sorusunu sormak gerekmektedir. Yine işten çıkarma sonucunda, potansiyel bir davayı mahkemelerin nasıl değerlendireceği de sorgulanmalıdır. Davaları en aza indirebilmek için işverenlerin işten çıkarılan kişiye kıdem tazminatını vermek ve kazanılmış süreleri derhal ödemek gibi dikkat etmeleri gereken bazı noktalar bulunmaktadır (DeCenzo, Robbins ve Verhulst, 2017: 99-100).

Yukarıda yönetim açısından ele alınan işten çıkarılma, bir çalışanın kariyerinde yüzleşebileceği en zor deneyimlerden biridir. İşten çıkarılan çalışanlar güçsüzlük duygusu hissederek kendilerinden şüphe etmektedirler. İşten çıkarma kararı performansa değil şirket birleşmesine bağlı olsa bile bu durum işten çıkarılan çalışanların kendi yeteneklerini sorgulamasına engel olamamaktadır. Bu zayıflıkları ortadan kaldırmak için olumlu bir tutum sergilenmeli, güçlü yanlara odaklanılmalıdır (Peppercorn, 2018). Ayrıca çalışanlara uyulması gereken kurallar ile ilgili açık bilgiler verilmeli ve çalışanların başarısız oldukları konularda onlara uyarılar yapılmalıdır (Armstrong, 2014: 259).

\subsection{1. İşten Çıkarmanın Hukuki Boyutu}

Çalışma hayatında iş sözleşmeleri tarafların anlaşması, ölüm ve belirli sürenin bitimi sebeplerinin yanı sıra fesih yoluyla da sona erebilmektedir (Çetin, Arslan ve Dinç, 2015: 214).

Fesih, iş sözleşmesinin tarafı olan işçi veya işverenin sözleşmeyi sona erdirmeye yönelik irade açıklamasıdır. Koşulları, hüküm ve sonuçlarına göre fesih bildirimli fesih (feshi ihbar) ve bildirimsiz (haklı sebeple fesih) olarak ikiye ayrılmaktadır. Bildirimli fesih yapıldığında, iş sözleşmesi fesih bildiriminin yapılmasından belirli bir süre sonra ortadan kalkmaktadır. İşs sözleşmesinin sona erdirilmesini gerektiren haklı sebeplerin mevcut olduğu bildirimsiz fesihte ise, iş sözleşmesi fesih beyanından itibaren sona ermektedir (Sümer, 2018: 98-99).

Bildirimli fesihle iş sözleşmesinin sona erdiği durumlarda, taraflardan biri sözleşmeyi bozacağını önceden karşı tarafa bildirmektedir. İş sözleşmesinin bildirimli feshinde, iş güvencesi unsuru dikkate alınmaktadır (Çetin ve diğg., 2015: 214). İş güvencesi koşullarının gerçekleşmediği durumlarda, işveren feshi geçerli nedene dayandırmak, yazılı fesih beyanı yapmakla yükümlü değildir. Aynı şekilde işçi de iş akdini geçerli sebebe dayanmaksızın feshedebilmektedir. İş güvencesi kapsamındaki işçilerin iş sözleşmelerinin bildirimli feshi ise geçerli sebebe bağlı olarak sonlandırılmaktadır (Sümer, 2018: 102-110).

Geçerli sebep kavramı, haklı sebeple fesih düzeyine ulaşmayan ancak iş ve iş yeri süreçlerini olumsuz etkileyen sebeplere dayanarak feshi makul gösteren bir olgudur (Dulay, 2010: 965). Örneğin bunlardan birini oluşturan işçinin yetersizliğinden kaynaklanan sebepler genel olarak performans, verim ve uyum unsurlarını odağına almaktadır. İşçinin ortalama olarak benzer işi görenlerden daha az verimli çalışma, işe yoğunlaşmanın giderek azalması, gösterdiği niteliklerden beklenen daha düşük performansa sahip olma ve uyum yetersizliği geçerli sebeple fesih gerekçesi oluşturmaktadır. Ancak burada vurgulanmalıdır ki Yargıtay’a göre, performans düşüklüğüne bağlı iş sözleşmesinin feshinde objektif esaslara dayalı performans ölçüm sisteminin olması gerekmektedir (Sümer, 2018: 105). Öyleyse, performans değerlendirme bir işten çıkarma "aracı" olabilir mi? Süreçlerin objektif ve sistematik bir şekilde yürütülmesi bu sebeplerle işten çıkarılan çalışanların yönetiminde dikkat edilmesi gereken noktalardır. Veya haklı sebep niteliği taşımamakla birlikte, işçinin iş sözleşmesine aykırı davranışları bulunabilmektedir. İşverene zarar vermek, arkadaşlarını işverene karşı kışkırtmak, iş akışını durduracak şekilde uzun telefon görüşmeleri yapmak, iş saatleri içinde iş amacı dışında sık sık internete girmek, 
amire ya da çalışma arkadaşlarına saygı sınırlarını aşan söz ve davranışlarda bulunmak gibi durumlar işçinin davranışlarından kaynaklanan geçerli sebepleri oluşturmaktadır (Çelik, Canikoğlu ve Canbolat, 2018: 502-514).

Fesih bildirimine itiraz etmek isteyen işçinin, bildirimde sebep gösterilmediği veya gösterilen sebebin geçerli bir sebep olmadığı iddiası ile fesih bildiriminin tebliğ tarihinden itibaren bir ay içinde arabulucuya başvurması gerekmektedir. Arabuluculuk yoluyla anlaşmaya varılamaması durumunda iki hafta içinde iş mahkemesine dava açılabilmektedir (Sümer, 2018: 107-108). 7036 sayılı İş Mahkemeleri Kanunu, işe iade davalarında arabulucuya başvurmuş olma şartı aramaktadır (md.3/1).

İş sözleşmesinin haklı sebeple derhal feshi (bildirimsiz fesih), taraflardan birinin haklı bir sebebe dayanarak sözleşmeyi bozduğunu bildirip derhal sona erdirmesi anlamına gelmektedir. Bildirimli feshin aksine, haklı sebeplerle yapılan fesihte iş sözleşmesi belli bir sürenin geçmesi beklenmeksizin derhal yapılmaktadır (Akyiğit, 2013: 172). Borçlar Kanunu'na göre, sözleşmeyi sona erdiren taraftan dürüstlük kurallarına göre hizmet ilişkisini sürdürmesi beklenemeyen bütün durum ve koşullar haklı sebep olarak kabul edilmektedir (md.435).

İş Kanunu'nda ise feshi haklı kılan sebepler; sağlık sebepleri, ahlak ve iyi niyet hallerine uymayan haller ve benzerleri, zorlayıcı sebepler olmak üzere üç başlık altında ifade edilmiştir (md.25). İşçi ve işveren için iş sözleşmesinin bildirimsiz feshini gerektiren haklı sebepler iki ayrı maddede düzenlenmiştir (Çelik ve diğ., 2018 : 576). İşverenin sağlık sebeplerine dayanarak haklı sebeple iş sözleşmesini feshetmesinde işçinin kendi kastıyla hastalığa yakalanması veya engelli hale gelmesi unsurları söz konusu olmaktadır. İşçinin tutulduğu hastalığın tedavi edilemeyecek nitelikte olduğu ve iş yerinde çalışmasında sakınca bulunduğunun tespit edilmesi durumlarında iş sözleşmesi bildirim süreleri beklenmeksizin feshedilmektedir. İşçiyi bir haftadan fazla süre ile çalışmaktan alıkoyan zorlayıcı bir sebebin ortaya çıkmasıyla da iş sözleşmesi sonlandırılabilmektedir (İşKK. md.25). Aynı şekilde ahlak ve iyi niyet kurallarına uymayan haller ve benzerleri durumlarının ortaya çıkmasıyla da işveren haklı sebeple derhal fesih yapabilmektedir. İşçinin işvereni yanıltması, şeref ve namusa dokunacak davranışlarda bulunması, devamsızlık unsurları bildirim süreleri uygulanmaksızın işten çıkarmaya yol açmaktadır. Yine işçinin işverenin başka bir işçisine cinsel tacizde bulunması, doğruluk ve bağlılı̆̆a uymayan davranışlar sergilemesi durumlarında da iş sözleşmesi haklı sebeplerle feshedilmektedir (İşK. md.25).

\subsection{Sosyal Medya}

Psikososyal bir varlık olan insan sosyal bir ortamda kendine özgü kişilik yapısıyla diğerleriyle etkileşim halinde yaşamaktadır. İnsanlar bilgi, düşünce ve duygu aktarımını günlük ve çalışma yaşamlarında iletişim vasıtasıyla gerçekleştirmektedirler. Bu bakımdan iletişim insanların davranışlarının anlaşılmasını sağlayan bir araçtır (Sabuncuoğlu ve Tüz, 2003: 64). Bireylerin iç veya dış çevreyle bu şekilde etkileşiminde kullandığı araçların ilişkileri geliştiren ve anlaşma ortamı sağlayacak nitelikte olması gerekmektedir. Günümüz bilgi çağında teknolojide yaşanan değişim ve gelişmeler bireylerin çalışma ve düşünce biçimlerinin yanı sıra iletişim yöntemlerinin de değişmesine neden olmuştur. Bireylerin bilgisayarlar, cep telefonları veya tabletler aracılığıyla toplumsal, siyasal ve ekonomik paylaşımlar yapmalarını sağlayan internet insanların ve örgütlerin zamandan ve mekândan bağımsız bir şekilde bilgiye erişimlerini, paylaşımlarını ve bilginin serbestçe dolaşımını sağlamaktadır. (Bozkurt, 2005: 39). İnsanlar tarafından yaygın olarak kullanılan sosyal medya her kesimin sosyal ihtiyaçlarına cevap veren ve bilgi dağıtımında oldukça hızlı işleyen iletişim araçlarındandır.

İnsanların psikolojik ve sosyal bazı gereksinimlerini tatmin etmek amacıyla aktif olarak belirli medya araçlarını veya diğer kaynakları tercih etmesi düşüncesine dayanan kullanımlar ve doyumlar yaklaşımının temeli psikolog Elihu Katz (1959) tarafından atılmıştır. Katz (1959) popüler kültür ile köprü kurma potansiyeline de sahip olan kullanımlar ve doyumlar yaklaşımı çalışması ile medyanın insanlara ne yaptığından ziyade insanların medyayla ne yaptığına dikkat çekmiştir (Katz, 1959: 2; Yaylagül, 2014: 71).

Sosyal medya, teknoloji aracılığıyla kullanıcılar tarafından oluşturulan içeriklerin ve sosyal etkileşimin birleştiği çeşitli web siteleri için kullanılan bir şemsiye terimdir. Bu platformlar genellikle kullanıcıların içerik oluşturmasına, paylaşmasına, indirmesine, bir profil oluşturarak istediği kişisel bilgileri yayınlamasına ve başkalarıyla bağlantı kurmasına izin vermektedir (Brown ve Dent, 2017: 196). Sosyal medya devaml güncellenebilmesi, kullanım kolaylığı ile çok sayıda kişinin aynı anda paylaşım yapmasına imkân vermesi gibi çeşitli özellikleriyle insanların sürekli takip ettikleri bir iletişim mecrası haline gelmiştir. Sosyal medyada her tıklama, paylaşım, beğenme ve gönderi bir bağlantı oluşturur, bir ilişki başlatır. Sosyal medya ile ilgili tüm bu eylemlerin en sıkıntılı tarafı yayınladığınız bir şeyin artık sizden çıkıp sonsuza kadar internette yer alacak bir nesneye dönüşmüş olmasıdır (Bucher, 2015: 1). 'We are social' internet araştırmaları platformunun açıkladığı 
rakamlara göre dünyada 2019 itibariyle 4,39 milyar internet (dünya nüfusunun yaklaşık \%57'si) ve 3,48 milyar (dünya nüfusunun yaklaşık \%45'i) sosyal medya kullanıcısı bulunmaktadır. Günde 7 saate yakın internet kullanan insanlar bunun yaklaşık 3 saatini sosyal medyada geçirmektedirler. Aynı zamanda iyi bir zaman hırsızı olan sosyal medya, platform sahipleri için bir iş modeli iken insanlar için hayali karakterler yaratabildikleri eğlenceli bir video oyunu kimileri içinse bir kariyer seçeneği olarak değerlendirilmektedir (Bucher, 2015: 1).

Bireyler tarafından bir nevi gerçekten hayattan kaçış yolu olarak görülen sosyal medya, bloglar, forumlar, sosyal ağlar, video ve fotoğraf paylaşımı imkânları ile insanları etkileşime girmeye, düşünceleri paylaşmaya ve bilgileri çevrimiçi tartışmaya teşvik eden internet tabanlı araçlardır (Castells, 2005: 477; Mooney, 2015: 11). Sosyal medya hayatın her anına dokunma ve her an kullanıcısının yanında olma özellikleri ile bir anlamda yaşamın akışını belirleyen ve yönlendiren bir işleve de sahiptir. Sosyal medya kendi değerleri ve çıkarları doğrultusunda adeta insanların gördüklerini ve duyduklarını şekillendirmektedir. Bununla birlikte mesafeli yakınlıklar, mesafesiz ilişkiler yaratan sosyal medya iletişim ve toplumsallaşma süreçleri açısından sadece niceliksel değil aynı zamanda niteliksel bir dönüşümü de ima etmektedir (Dellaloğlu, 2015: 24). Sosyal medya bir yandan kişiyi bir şekilde olduğu haliyle bırakırken diğer yandan mahremiyeti politikleştirmektedir (Bezci, 2015: 34).

Sosyal medya platformlarına gösterilen yoğun ilgi bireyler/örgütler açısından fikir paylaşımı ve etkileşim biçimini de etkilemiştir. Sosyal medya platformları insanlara çevrimiçi etkileşimler yoluyla ilişkiler kurma ve sürdürme konusunda yeni bir imkân sağlamıştır (Waters ve Ackerman, 2011: 102). Sosyal medya aynı zamanda insanların her an her saniye paylaşımda bulunarak tecrübelerini, beklentilerini ve korkularını yansıtan parçaları diğerleriyle paylaştığı ve sosyal bağlar kurmasına yardımcı olan bir ağ işlevi görmektedir (Hermida, 2017: 126). Her an her yerde erişim imkânı olan sosyal medya kaotik ve sistemsiz yapısı ile bireylerarası ilişkileri de hızla değiştirmektedir. Bireyler sosyal medyada kullanıcı olarak tek bir tuş hareketi ile bir gruba, hiç gitmedikleri bir yere veya bir ideolojiye dahil olabilmektedirler. Yine bir tek tık hareketiyle farklı dünyalara girip çıkabilen bireyler tüm bu eylemleri ve düşünceleri inkâr edebilmektedirler. Teknoloji bir yandan hayatı kolaylaştıran tüm imkanlarıyla insanları cezbederken diğer taraftan herkesi her an ulaşabilir kılarak özel hayat ve çalışma yaşamı arasındaki sınırın bulanıklaşmasına sebep olmaktadır (Önkal ve Gündüzlü, 2015: 38; Losyk, 2016: 17). Sosyal medyada sosyal olmak, sadece sistemin sınırları içerisinde bağlantılar oluşturmaktan geçmektedir (Bucher, 2015: 1).

Yaşadığımız bilgi çağında çeşitli teknolojilerle desteklenen medya ya da popüler kültür aracılığıyla gözetlenen bireyler sabah gözlerini açar açmaz hatta gece yatana dek veri üretip paylaşmaya gönüllü ya da gönülsüz veri işçileri olarak bu sisteme hizmet etmektedir. Hegel tarafından gazeteler için kullanılan çağdaş insanın sabah dualarının yerini aldığı yorumu günümüz insanı açısından sosyal medya için geçerli olmuştur (Hegel, 2010). Sosyal medya kullanıcıları gözetlendiklerini bildikleri bir ortamda paylaşımlar yapmakta, bir yandan da diğerlerini gözetlemektedirler (Tatlı, 2016: 82). Bununla birlikte bilgi teknolojileri devasa büyüklükteki kitleleri gözetimciler için görünmeksizin ya da bilinmeksizin izlenebilir hale getirmiş, sosyal medya platformlarını sıklıkla kullanan bireyleri Foucault'un panaptikon, Orwell'in büyük birader metaforunda olduğu gibi daha yoğun gözetim tehlikesiyle karşı karşıya bırakmıştır. Çok sayıda kullanıcının yer aldığı sosyal medya platformlarında bilgi teknolojileri aracılığıyla gözetim olgusu yaygınlaşmakta ve sıradanlaşmaktadır (Şener ve Kuş, 2015: 54). Foucault'un bireylerin fiziksel olarak dış dünyadan uzun süre ayrı tutulduğu hapishaneler ile ilgili çalışmasında mahkumların davranışları üzerindeki kontrolün en üst düzeye çıkarılmak istenmesi gözetimin niteliğini açıkça göstermektedir. Foucault'un kuruluşlardaki faaliyetlerin denetimi olarak bahsettiği gözetim olgusu Giddens (1997) tarafından modern toplumlarda gündelik hale geldiği ifade edilmiştir. İnsanların dış sosyal çevreden uzak tutularak bir nevi hapsedildiği gözetim toplumunda Foucault, "hapishanelerin fabrikalara, okullara, kışlalara ya da hastanelere benzemesi şaşırtıcı mıdır?" diye sormuştur. Foucault, görünürlülüğün bir tuzak olduğundan bahsetmektedir. Foucault'un panapticon metaforunda görülen ama göremeyen birey gerçekten bir bilginin nesnesi iken iletişimin öznesi olamamaktadır (Bozkurt, 2005: 102-112).

\subsection{Mahremiyet}

Mahremiyet üzerine yapılan tartışmalar insanlık kadar eskidir. Bireyin bedeninin ve evinin korunmasıyla başlayan mahremiyet kişisel bilgilerin kontrol edilmesi yönünde gelişim göstermiştir (Holvast, 2008: 13). Stone vd. (1983)'e göre mahremiyet bireyin diğer bireyler, gruplar ve organizasyonlara karşı kendisiyle ilgili kişisel bilgileri kontrol etme yeteneğidir (Stone vd., 1983, s. 460). Bir başka ifade şekliyle mahremiyet birileri tarafından gözlenmeden bir şeyler yapabilmek ve başkalarının hakkımızda ne düşündüğünü kontrol edebilmek anlamına gelmektedir (Hermida, 2017: 19). Türk dil kurumuna göre sözlük anlamı gizlilik olan mahremiyet sosyoloji, psikoloji, ilahiyat, hukuk ve iletişim gibi çeşitli disiplinler tarafından incelenmektedir (TDK, 2019; Newell, 1995: 
87). Bazı araştırmacıların sosyal ilişki veya sosyal süreç olarak çevresel düzeyde, bazılarının ise sosyo-kültürel veya örgütsel düzeyde ele aldığı mahremiyet kavramı aleni olmaya, diğerleri tarafindan bilinmeye kapalı olma durumunu ifade etmektedir. Mahremiyet bireyin kendisi hakkındaki hangi bilgilerin başkalarına hangi koşullar altında iletilmesi gerektiğine karar verme hakkı olarak da tanımlanmaktadır (Altman, 1977: 67; Westin, 2003: 3). Sanayi devrimi sonrasında iş ve aile yaşamında meydana gelen değişimler, eğitim seviyesinin artması ve bilgi ve iletişim teknolojilerindeki gelişmeler mahremiyetin dönüşümünde etkili olmuştur (Şimşek, 2019: 14). Farklı bakış açıları ile ele alınan mahremiyetin bireysel olarak farklı algılanması, dönemden döneme farklı değerlendirilmesi, ekonomik, siyasi, kültürel ve sosyal alanlarda yaşanan değişimler nedeniyle sınırlarını belirlemek güçleşmekte ve tutarlı bir biçimde değerlendirilmesi zor olmaktadır (Korkmaz, 2013: 116).

Sosyal medya kullanıcılarının gözetleme ve gözetlenmeye ilişkin tutumları mahremiyetin sınırlarının farklı şekilde çizilmesine neden olmuştur. Teknolojinin gelişimiyle birlikte bilgi toplumuna geçiş hızlanmış bu da mahremiyetin aşınmasına ve bir gözetim topluluğunun oluşmasına yol açmıştır (Holvast, 2008: 13). Milyarlarca insanın sonsuz bir beğeni ve paylaşım seline kapıldığı bu sanal ortam eski çağlardan günümüze dek toplumlarda süregelen bir olgu olan mahremiyet kavramına ilişkin görüşleri de dönüşüme uğratmıştır. İnsanların kimi zaman bilgi alışverişi kimi zamanda sosyal ilişkiler için sosyal medya platformlarında kurdukları iletişim o anlık, gelip geçici olsa da veriler o anın ötesinde kalmaya devam etmekte, arkalarında dijital ayak izleri bırakmalarına neden olmaktadır. Bununla birlikte bireylerin sıkıntılarından kurtulmak ya da bunları düşünmemek için meşgul oldukları sosyal medya platformları bireylerin duyarsızlaşmasına ve benliklerinin körelmesine neden olmaktadır (Tatl1, 2016: 83). Bireylerin gerçek hayatta özen gösterdikleri ve bir nevi dışarıya kapattığı odası gibi görülen mahremiyet olgusu dış çevreye karşı korunup ifşa edilmezken, iletişim araçlarının yaygınlaşmasıyla birlikte sanal dünyaya açılmış ve önemini yitirmiştir.

Bireyler kimi zaman özgüven sorunu kimi zaman da aşağılık/üstünlük kompleksi gibi nedenlerden dolayı sanal âlemde kendilerine ya da başkalarına ait mahremiyet sınırlarını aşarak dikkat çekmeye ve dinlenen biri olmaya çalışmaktadırlar. Merak duygusu ile hareket eden bireyler sanal ortamda özellerini ve sırlarını paylaşarak ilgi topladıkça buradaki tecrübelerini gerçek yaşamlarında da uygulamaya başlamaktadırlar. Westin (1970), modern çağda mahremiyete yönelik tehditlerin kendini ifşa etme, merak ve gözetleme şeklinde üç kaynağı olduğunu ifade etmektedir (Yüksel, 2003: 185). İlk unsur olan tehdit, kendi bireyselliğine hapsolmuş bireyin bir tür iç dökme eylemi olarak kamusal alanda kendini ifşası/teşhiridir (Öztekin ve Öztekin, 2010: 533). Merak evrensel bir insani eğilim olarak tehdit oluştururken gözetim ise temel sosyal kontrol araçlarından biridir (Yüksel, 2003: 186). Kamu ve özel alandaki sınırların bulanıklaştığı günümüz teknoloji toplumunda kendi hapsolduğu alandan çıkmak isteyen birey bu sürece gönüllü olarak katılarak sosyal medyada kendini ifşa etmektedir. Birey, sosyal medya platformlarında sürekli izlendiğini ve gözetlendiğini bilmesine rağmen kendini ifşa etmekten geri durmamaktadır. Aksine birey gözetlenmeden zevk almakta, bu durum bireyi daha fazla kendini ifşa etmeye kışkırtmaktadır (Öztekin ve Öztekin, 2010: 539).

\subsection{Sosyal Medya Paylaşımlarının İşten Çıkarma Üzerine Etkisi}

Teknolojideki hızlı gelişmelerle birlikte sosyal medya kullanımı önemli ölçüde yaygınlaşmakta ve özellikle son dönemde iş̧̧ilerin sosyal medya aracılığıyla işverenin şeref ve namusuna dokunacak açıklamaları sık sık gündeme gelmektedir (Çelik ve diğ., 2018: 589). İşçiler sosyal medya hesaplarından işle ilgili şikâyetlerini veya işveren/işveren vekiline yönelik eleştirilerini paylaşmaktadırlar. İşçilerin sosyal medya hesaplarından işe/işverene yönelik "eleştirel” paylaşımları disiplin suçu oluşturmakta mıdır? Belki de bu noktada sorgulanması gereken temel problemlerden biri paylaşımların geçerli ya da haklı nedenle fesih oluşturup oluşturmayacağıdır. Mahkeme kararları incelendiğinde, işçinin sosyal medya aracılığıyla işveren/işveren vekili ya da bir işçisi hakkında şeref ve namusa dokunacak ifadeler kullanmasının işverenin haklı sebeple iş sözleşmesini sonlandırmasına imkân tanıdığı görülmektedir (Baybora, 2017).

İşçinin talimatlara aykırı bilgisayar, internet ve cep telefonu kullanımına işverenler tarafından çeşitli sınırlamalar getirildiği görülmektedir. Ancak bu sınırlamaların işçinin kişiliğinin korunması ilkesine, özel hayatın gizliliğine, düşünce ve kanaat özgürlüğü ilkesine ve haberleşme hürriyetine aykırılık teşkil etmemesi gerekmektedir. Konuya ilişkin Avrupa İnsan Hakları Mahkemesi’nin vermiş olduğu kararlara uyulması beklenmektedir (Keser, 2019: 486). Öte yandan, işçinin işyeri dışında olsa bile Twitter, Facebook gibi sosyal medya platformlarında işyerine, işyeri politikalarına, iş ilişkisine veya işverene ait özel bilgileri paylaşması işçinin özel yaşamına müdahale edilmesine zemin hazırlamaktadır (Kutsal ve Kolan, 2019: 495). 
Sosyal medyanın gözetlenmesi, online davranışların belli durumlarda kırmızı çizgiler oluşturduğu iş başvurularının elenmesinde işverenler için bir araç haline gelmektedir. Sosyal medya, çalışanlarla ilgili kararların verilmesinde yararlı olsa da çalışanlar tarafından sosyal medyanın kötüye kullanılması, işten çıkarma gibi çeşitli disiplin uygulamaları üzerinde tetikleyici bir etki yapmaktadır. Öyle ki çalışanların sosyal medya kullanımlarından dolayı artan işten çıkarmalar "Facebook paylaşımı sebebiyle işten çıkarma/kovma (Facebook Fired)" kavramının doğmasına sebep olmuştur (Hidy ve McDonald, 2013: 70-73). Sosyal medya olgusu, işyeri ve özel hayat arasındaki çizgiyi bulanık hale getirmektedir. Facebook, Twitter gibi sosyal medya uygulamaları, çalışanların iş dışındaki boş zamanlarında görüşlerini paylaşabileceği önemli platformlardır. Bu noktada da sorulması gereken temel soru şudur: “İşverenler, çalışanların sosyal medya paylaşımları üzerinde disiplin uygulama yetkisine sahip midir?". Özellikle de işyeri dışında ve çalışanların kendi erişimiyle yapılan paylaşımlarda işverenlerin kontrol yetkisi bulunmakta mıdır? Pek çok işletmede sosyal medya kullanımı için katı kural ve politikalarının belirlendiği bilinmektedir. Hatta bazı işverenler çalı̧̧anlarından Facebook şifrelerini talep etmekte ve böylelikle iş dışında da çalışanlarını kontrol edebilmektedirler (McGinley ve Stempel, 2012: 79-80). Sonuç olarak, gözetim mekanizmasından ne işyerinde ne iş dışında kaçmak mümkün görünmemektedir (Tartanoğlu, 2012: 227).

Sosyal medyaya bağlı işten çıkarma olgusu (the phenomenon of social media-driven dismissal), çeşitli araştırmacılar tarafindan ele alınmıştır. Pen (2016), "Never tweet: Social media and unfair dismissal" "adlı çalışmasında, işverenlerin çalışanların özel hayatlarını hangi ölçüde kontrol edebileceğini sorgulamıştır. Sosyal medya ve işten çıkarma olgusunun karmaşık bir problem olduğunu dolayısıyla çalışmaya karşı politik, kültürel ve ekonomik tutumların yeniden incelenmesi gerektiğinin altını çizmiştir (Pen, 2016: 271-274). "Blurred Boundaries: Social Media Privacy and the Twenty-First-Century Employee" adlı çalışmada ise araştırmacılar, işveren tarafindan sağlanan bilgisayarların özel ve kurumsal iletişimi ayırmadığını ileri sürmektedirler. Bu iletişim teknolojileri, ev ve işyeri arasındaki çizgiyi de bulanıklaştırmaktadır. Öte yandan, çalışanın kişisel bilgilerine işverenler, iş arkadaşları, müşteriler ve diğer izleyiciler tarafindan kolay bir şekilde erişilebilmektedir. Bu noktada çalışanların mahremiyet beklentileri aslında bir tezatlı̆g 1 da beraberinde getirmektedir. Çalışanlar işverenlerin gözetiminden rahatsız olmaktadırlar ve mahremiyete dikkat çekmektedirler ancak işverenler tarafindan kolayca erişilebileceğini bilmelerine rağmen kişisel bilgilerini paylaşmaya da devam etmektedirler (Abril, Lewin ve Riego, 2012: 64-66).

\section{AMAÇ VE ÖNEM}

Bu çalışmada, "sosyal medya paylaşımları sebebiyle işten çıkarma" olgusu ele alınmaktadır. Çalışmanın ana amacı, çalışanların sosyal medya paylaşımlarının işten çıkarma sebebi oluşturup oluşturmayacağının incelenmesidir. Ayrıca ana amacın kapsamlı bir şekilde analiz edilebilmesi için çalışanların mahremiyete yönelik tutumlarının sosyal medya paylaşımlarına etkisi ve bu etkinin işten çıkarmada hangi rolü oynadığının incelenmesi çalışmanın alt amaçları olarak belirlenmiştir.

Sosyal medya platformları başta işe alım (Vardarlıer, 2018; Bozkurt ve Triki, 2016) ve işten çıkarma uygulamaları (Thornthwaite, 2017; Hidy ve McDonald, 2013; Pen, 2016) olmak üzere araştırmacılar tarafından IKKY'nin farklı işlevleri açısından ele alınmıştır. Bu çalışma, çalışanların işten çıkarılmalarıyla sonuçlanan sosyal medya paylaşımlarına odaklanması ve işten çıkarma yaptırımı ile mahremiyet arasında kurulabilecek ilişkiyi incelemesi bakımından önceki çalışmalardan farklılaşmaktadır. Yine önceki araştırmalara bakıldığında, işten çıkarma yaptırımının genel olarak hukuki boyutuyla ele alındığı dolayısıyla konuyu sosyal medya, mahremiyet, ifşa ve gözetim bağlamında inceleyen çalışmaların sınırlı olduğu görülmüştür. Bu çalışma, Türkiye örneği üzerinden çalışanların yaptıkları sosyal medya paylaşımları, işten çıkarma ve mahremiyet bağlamında değerlendirilmiştir. İşten çıkarmaya modern mahremiyet tehditleri olan gözetim ve ifşa gözlüğünden bakılan bu çalışmada, İKY alanına yeni bakış açıları kazandırılmaya çalışılmaktadır. Tüm bunlardan hareketle araştırmada "Çalışanların sosyal medya paylaşımlar işten çıkarma sebebi oluşturmakta mıdır?" problemine cevap aranmaktadır. "Çalı̧̧anların mahremiyete yönelik tutumları sosyal medya paylaşılarını etkilemekte midir?" ve "Çalışanların mahremiyete yönelik tutumları işten çıkarma sebebi oluşturmakta mıdır?" ifadeleri araştırma kapsamında sorgulanmaktadır. 


\section{YÖNTEM}

$\mathrm{Bu}$ çalışmada derinlemesine analizler yapabilme amacıyla nitel araştırma türlerinden örnek olay yöntemi tercih edilmiştir. Örnek olay çalışması yöntemi, olguları tanımlamak ve açıklamak amacıyla bir ya da birden fazla olayın sistematik bir şekilde derinlemesine incelenmesi anlamına gelmektedir. Basit ya da karmaşı olguları

inceleyen bir nitel araştırma yaklaşımı olarak örnek olay çalışması teorilerden yararlanmakta ve teorilere anlamlı katkılar sunmaktadır (Berg ve Lune, 2015: 354). Örnek olay çalışmaları deneysel, tarama ya da tarihsel araştırmalardan veri toplama ve veri analizinde tek bir yönteme bağlı kalmama konusunda farklılaşmaktadır. Örnek olay çalışması, bir ya da birkaç örnek olayın pek çok kaynaktan elde edilen ayrıntılı verilerle betimlenerek olayla ilgili temaların raporlanmasıdır. Nitel örnek olay çalışmaları belirlilik, betimleme ve sezgisellik gibi özellikleri içinde barındırmaktadır. Örnek olayların belirli bir olaya/olguya odaklanması belirlilikle ifade edilmektedir (Cresswell, 2007'den aktaran; Merriam, 2015: 40-46). Bu çalışmada, işten çıkarma ve sosyal medya olgularına odaklanılmaktadır. Yine örnek olayların "bu neyin örnek olayı?” sorusuna cevap verebilir niteliklere sahip olması beklenmektedir (Berg ve Lune, 2015: 355). Örnek olayların bir diğer özelliği ise daha önceden bilinmeyen anlamları ve ilişkileri ortaya çıkaran sezgiselliktir. Örnek olay çalışmalarında incelenen durumlar somut bir şekilde yoğun olarak betimlenmektedir (Merriam, 2015: 44-52).

İşten çıkarma ve sosyal medya olgularını inceleyen bu araştırmada, nitel bir yaklaşımla dört örnek olay incelenmektedir:

- Mesai saatleri içinde sosyal medyadan çalışma disiplinini etkileyecek nitelikte fotoğraf paylaşılması/Geçerli sebeple fesih

- Çalışanın raporlu gününde plajda tatil kıyafetleriyle çekildiği fotoğrafı sosyal medyadan paylaşması/Haklı sebeple fesih

- Çalışanın sosyal medyadan insan kaynaklarına sataşma niteliğindeki mesajları paylaşması/Haklı sebeple fesih

- Çalışanın iş sözleşmesini "kölelik sözleşmesi” olarak nitelendirerek sosyal medyadan paylaşması/Geçerli sebeple fesih

Örnek olayların belirlenmesinde elemeci ve eleştirel bir yaklaşım güdülerek sosyal medya paylaşımları sebebiyle işten çıkarma olgusunu temsil eden 2016-2018 yılları arasındaki Yargıtay kararları incelenmiştir. Çok sayıda Yargıtay kararı incelenmiş bazıları olguyu temsili yetersiz olduğu gerekçesiyle elenmiş ve örnek olayların yakın tarihli olmasına özellikle dikkat edilmiştir. Yine örnek olayların belirlenmesinde özellikle yazılı basına da yansıyan örneklerden hareket edilmiştir.

Araştırma kapsamında, nitel veri toplama yöntemlerinden biri olan dokümanlar kullanılmaktadır. (Merriam, 2015: 131). Dokümanlardan elde edilen verileri anlamlandırma ve yorumlama işlemi içerik analizi yöntemiyle yapılmaktadır. İçerik analizi, anlamları tespit etmeye yönelik verilerin ayrıntılı ve sistematik olarak incelenmesi çabasıdır (Berg ve Lune, 2015). Genel bir çerçeve içinde yapılan kodlamayla (Yıldırım ve Şimşek, 1999: 162-175) kodlama sürecindeki ilişkiler temalar haline gelmektedir (Merriam, 2013: 173). Çalışmada belirlenen temalar, bulgular kısmında sunularak değerlendirilmiştir.

\section{BULGULAR}

$\mathrm{Bu}$ çalışmada sosyal medya sebebiyle işten çıkarma olgusunun işlendiği Yargıtay kararları örnek olay çalışması ile sunulmaktadır. Örnek olaylar derinlemesine incelenmeden önce, araştırmanın amacı doğrultusunda özet bir tabloyla ifade edilmektedir. 
Tablo 1. İçerik Analizine İlişkin Bulgular

\begin{tabular}{|c|c|c|c|c|}
\hline \multirow{2}{*}{$\begin{array}{l}\text { Yıl/Karar } \\
\text { Numarası }\end{array}$} & \multirow{2}{*}{ Örnek Olay } & \multicolumn{2}{|c|}{ Mahremiyete Yönelik Tehditler } & \multirow{2}{*}{ Hukuki Sonucu } \\
\hline & & Tema & Kodlar & \\
\hline $2016 / 11591$ & $\begin{array}{l}\text { Çalışanın, iş arkadaşlarıyla birlikte } \\
\text { mesai saatleri içerisinde, hasta } \\
\text { yataklarının üzerine çıkıp kurumu } \\
\text { ve mesleğini küçük düşürecek } \\
\text { şekilde fotoğraf çektirmesi, daha } \\
\text { sonra bu fotoğrafi sosyal medya } \\
\text { hesabından bir grup aracıllğıyla, } \\
\text { kurum isim ve logosunu açıkça } \\
\text { beyan ederek, "hasta gelmesin diye } \\
\text { dua ederken, ...Hastanesi" } \\
\text { başlığıyla facebook adlı sosyal } \\
\text { paylaşım sitesinde yayınlaması }\end{array}$ & İfşa & $\begin{array}{c}\text { Açıkça Beyan } \\
\text { Facebook } \\
\text { Sosyal Medya } \\
\text { Fotoğraf Çektirmesi } \\
\text { Mesai Saatleri } \\
\text { Küçük Düşürecek }\end{array}$ & $\begin{array}{l}\text { İşverenin geçerli sebebe } \\
\text { dayanarak işçinin iş } \\
\text { sözleşmesini feshetmesi/ } \\
\text { işyerindeki ç̧alışma } \\
\text { disiplinini ve iş akışını } \\
\text { etkileyecek nitelikte olup } \\
\text { artı davalı işverenden } \\
\text { davacı ile çalışmasının } \\
\text { beklenememesi }\end{array}$ \\
\hline 2017/12196 & $\begin{array}{l}\text { Çalışanın istirahat raporu aldığ } \\
\text { dönemde Giresun iline gitmesi ve } \\
\text { orada plajda tatil kıyafetleri ile } \\
\text { çekilmiş fotoğraflarını paylaşması }\end{array}$ & İfşa & $\begin{array}{c}\text { İstirahat Raporu } \\
\text { Plaj } \\
\text { Tatil Kiyafetleri } \\
\text { Fotoğraf Paylaşması } \\
\end{array}$ & $\begin{array}{l}\text { İşverenin haklı sebebe } \\
\text { dayanarak iş sözleşmesini } \\
\text { feshetmesi/doğruluk } \\
\text { bağl1lığa aykırılık }\end{array}$ \\
\hline $2017 / 14208$ & 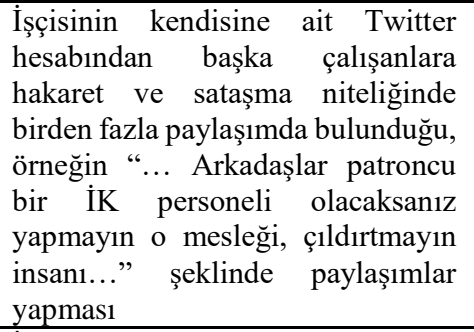 & Gözetim & $\begin{array}{l}\text { Hakaret ve Sataşma } \\
\text { Twitter } \\
\text { Birden fazla paylaşım }\end{array}$ & $\begin{array}{l}\text { İşverenin haklı sebebe } \\
\text { dayanarak iş sözleşmesini } \\
\text { feshetmesi/işyerindeki } \\
\text { başka bir işyeri çalışanına } \\
\text { hakaret ve sataşma }\end{array}$ \\
\hline $2018 / 13723$ & $\begin{array}{l}\text { İş̧̧inin, müşteri temsilcisi/sosyal } \\
\text { medya uzmanı olarak görev } \\
\text { yaparken yazılı savunmasında da } \\
\text { kabul ettiği üzere, işe giriş } \\
\text { esnasında imzaladığı iş sözleşmesi } \\
\text { için Facebook hesabında kurumsal } \\
\text { müşteri olan ...'in adını vererek } \\
\text { "Bugün yaptığım iş sözleşmesinde } \\
46 \text { sayfa okudum ve imzaladım. } \\
\text { Artık köle olmaya hazırım" } \\
\text { şeklinde paylaşımda bulunması }\end{array}$ & Gözetim & $\begin{array}{c}\text { Facebook } \\
\text { Köle } \\
\text { Paylaşım } \\
\text { Adını vererek }\end{array}$ & 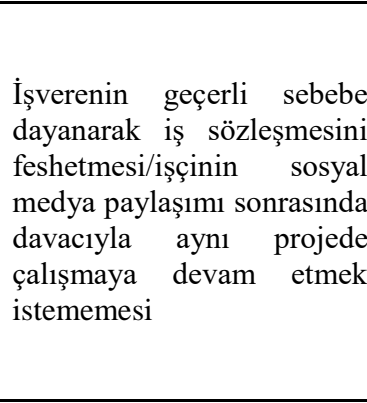 \\
\hline
\end{tabular}

Çalışmada insan kaynakları yönetiminin işten çıkarma fonksiyonu, hukuki olarak işverenin işçinin iş sözleşmesini geçerli ve haklı sebebe dayanarak fesih etmesiyle temsil edilmiştir. Şekil 1'deki gibi işten çıkarma olgusu çalışanların sosyal medya paylaşımları ve mahremiyet bağlamında değerlendirilmiştir.

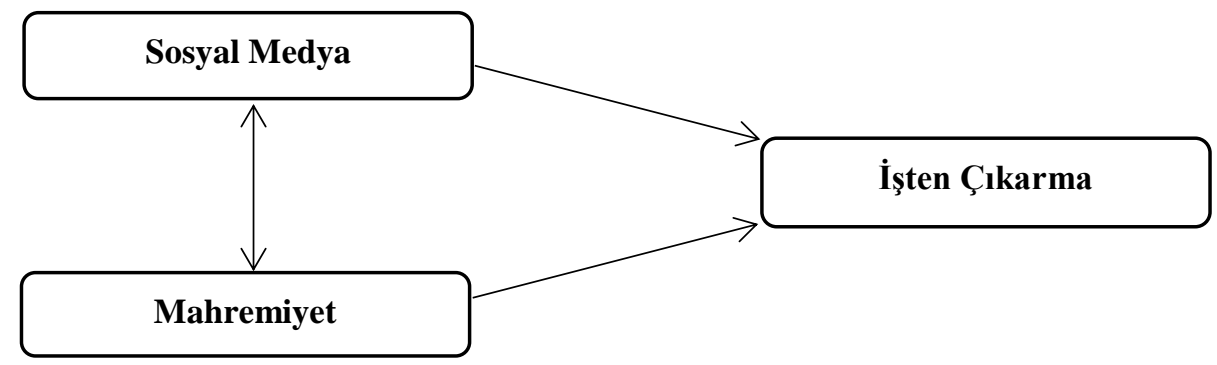

Şekil 1. İşten Çıkarma, Sosyal Medya ve Mahremiyet İlişkisi 


\title{
Örnek Olay 1
}

\author{
Yargitay 7. Hukuk Dairesi
}

\section{Esas Numarası: 2015/46017}

\section{Karar Numarası: 2016/11591}

\section{Karar Tarihi: 26.05.2016}

Dava: Işse iade

Olay: Somut olayda, daval şirkete ait ... Hastanesinde erkek hemşire olarak çalışan davacının iş akdine 13.11.2014 tarihinde ... çalışma saatleriniz içerisinde acil servis hasta yatakları üzerinde arkadaşlarınız ile kurumu ve mesleğinizi küçük düşürecek şekilde fotoğraf çektirerek, bu fotoğrafları kurumumuzun isim ve logosunu kullanarak sosyal medya üzerinden paylaştığınız sabit olarak tespit edilmiştir. Yaptı̆̆ınız bu davranış mesai saatleri içerisinde işinizi ciddiye alarak çalışmadığınızı göstermektedir. Kurum kültürüne ve genel iş hayatı kurallarına uymadı̆̆ınızdan 4857/25-II-e gereği doğruluk ve bă̆lllı̆̆a uymayan davranışlarda bulunmanız dolayısıyla iş akdine son verilmiştir.

02.11.2014 tarihinde "facebook”' adlı sosyal paylaşım sitesinde “...” isimli bir grup içerisinde yayınlanan hasta gelmesin diye dua ederken biz, ... Hastanesi” "başlıkll, davacı ile birlikte 3 kişinin hasta yataklarl üzerinde bağdaş kurup oturduğu ve ellerini havaya kaldırarak dua ettikleri fotoğrafin davalı işverence fesih nedeni yapıldı ̆̆ anlaşılmaktadır. Paylaşılan bu fotoğrafta davalı kurumun isim ve logosu kullanıldiğ gibi fotoğrafta davacının üzerinde formasının ve yaka kartının da bulunduğu görülmektedir. Sözü edilen paylaşım 1.285 kişi tarafindan beğenilmiş ve fotoğrafin altına 52 yorum yapılmıştır. Fotoğrafin yayınlandı̆̆l... grubunun yaklaşık 13.102 üyesi olduğu anlaşılmaktadır.

Yargıtay Kararı: Davacının 12.11.2014 tarihli savunması ile aynı gün temyiz incelemesi yapılan Dairemizin 2016/10461 Esas sayılı dava dosyasında aynı paylaşım nedeniyle iş akdi feshedilen işçinin savunmasından fotoğrafların mesai saatleri içerisinde çekildiği ve paylaşılmasına davacının rızasının bulunduğu anlaşılmaktadır.

Davacının mesai saatleri içerisinde çekilen ve paylaşılacağının bilindiği fotoğraflarının binlerce kişi tarafindan izlenebilecek bir sosyal paylaşım sitesinde yayılnlanması işyerindeki çalışma disiplinini ve iş akışını etkileyecek nitelikte olup artık davalı işverenden davacı ile çalışması beklenemeyeceğinden somut olayda haklı bir fesih nedeni bulunmasa bile fesih için geçerli bir nedenin bulunduğunun kabulü gerekmektedir.

(Kaynak: https://legalbank.net/belge/y-7-hd-e-2015-46017-k-2016-11591-t-26-05-2016-ise-iade-istemi-calismasaatleri-icerisinde-arkadaslar/2610486).

\section{Değerlendirme}

Örnek olayda çalışanın mesai saatleri içinde çalıştığı kurumun isim ve logosunu kullanarak sosyal medya hesabı üzerinden fotoğraf paylaşması Yargıtay tarafından işyerindeki çalışma disiplinini ve iş akışını etkileyecek nitelikte bulunmakta, dolayısıyla işçinin iş sözleşmesinin sonlandırılmasında geçerli sebep olarak görülmektedir. İş kanunun 18. maddesine göre, işveren iş güvencesi olan çalışanın iş sözleşmesini sonlandırırken geçerli sebebe dayandırmak zorundadır. Örnek olayda, paylaşımın 1285 kişi tarafından beğenilmesi ve fotoğrafın altına 52 adet yorum yapılması davanın seyri için göze çarpan bir nitelik oluşturmaktadır. Yargıtay’ın verdiği kararda da görüldüğü gibi çalışanın mesai saatleri içerisinde kendi rızasıyla paylaştığı fotoğrafların binlerce kişi tarafından izlenebilecek sosyal medya hesabında paylaşılması haklı bir sebep oluşturmasa bile işyerindeki çalışma disiplinini bozduğu için geçerli bir sebebe dayandırılarak çalışanın iş sözleşmesi feshedilmiştir.

Sosyal medyaya olan ilginin artmasıyla birlikte mahremiyet konusu da sık sık gündeme gelmeye başlamıştır. Bireyler tarafından sosyal medya hesaplarının bütün gizlilik ayarları yapılmış olsa bile yine de bazı sosyal paylaşımlar işverenlerin gözünden kaçmamaktadır. Bir işverenin çalışanın sosyal medya sayfasına erişmesi aslında birisinin günlüğüne okumaya benzer şekilde mahremiyet ihlalidir (Thornthwaite, 2013: 6). Bunlar doğrultusunda örnek olay mahremiyet açısından değerlendirildiğinde, çalışanların mahremiyet sınırlarını göz ardı ederek binlerce kişinin etkileşimde bulunduğu bir ortamda paylaşım yaptıkları görülmektedir. "İşverenler çalışanların sosyal medya paylaşımları üzerinde disiplin uygulamaya sahip midir?” sorusu örnek olayda cevap bulmaktadır. Mesai saatleri içerisinde iş disiplinini bozacak paylaşımlar işverene geçerli sebeple fesih yetkisi vermektedir. Sonuç 
olarak bir mahremiyet tehdidi olarak çalışanın mesai saatlerinde sosyal medya paylaşımları yoluyla kendini ifşa davranışı bir işten çıkarma sebebi oluşturmaktadır.

\section{Örnek Olay 2}

\section{Yargitay 9. Hukuk Dairesi}

\section{Esas Numarası: 2016/17532}

\section{Karar Numarası: 2017/12196}

\section{Karar Tarihi: 06.07.2017}

Dava: İşe iade

Olay: Davalı vekili, davacının güveni kötüye kullanması, doğruluk ve bağlllı̆ga uymayan davranışlarda bulunması nedeniyle iş sözleşmesinin geçerli nedenle feshedildiğini, ... hastallk dolaylstyla rapor ald̆ğ bu dönemde sosyal paylaşım sitelerinden birinde "herkese açık" olarak deniz kenarında tatil yaptı̆̆ını gösterir fotoğraflar paylaştı̆̆ını, davacının işi gereği yaptı̆̆ telefon görüssmelerinde ve ankette kattllmclya küfür ettiğinin tespit edildiğini, bu nedenlerle davacının sözleşmesinin müvekkili tarafindan feshedildiğini savunarak davanın reddini talep etmiş̧tir.

Yargıtay Kararı: Dosyadaki bilgi ve belgelerden davacının istirahat raporu aldığı dönemde Giresun iline gittiği ve orada plajda tatil kiyafetleri ile çekilmiş fotoğraflarını paylaştığı, dosya kapsamiyla sabittir. Bu durum, kullanılan istirahat raporunun gerçeğe aykırt olduğunun açık delili olup raporlu olduğunu bildiren iş̧̧inin raporun aksine tatile gitmesi doğruluk ve bağlllığa aykır olup hakl fesih için yeterlidir. Açıklanan nedenle işveren feshinin haklı nedene dayandığının kabulü ile davanın reddi gerekirken yanılgıll değerlendirmeyle kabulüne karar verilmesi hatalidir.

(Kaynak: https://legalbank.net/belge/y-9-hd-e-2016-17532-k-2017-12196-t-06-07-2017/2881519/06+07+2017 ++2016_17532+2017_12196).

\section{Değerlendirme}

İşveren, ahlak ve iyi niyet kurallarına uymayan haller ve benzerleri durumlarının ortaya çıkmasıyla haklı sebeple derhal fesih yapabilmektedir. Örnek olayda, çalışanın raporlu olduğu günde sahil kenarından fotoğraflar paylaşmasının doğruluk ve bağlılığa uymayan davranış olarak değerlendirildiği görülmektedir (İşK. md.25).

Modern toplumda, mahremiyete yönelik ihlallerin en ilginç biçimi bireyin bilerek ve isteyerek kendini teşhir etmesi anlamına gelen kendini if̧̧a davranışıdır. Gözetleyen, gözetlenen, gözetlendiğini bilen ve bundan zevk alan birey, sosyal medyada kendini ifşa ederek mahremiyet endişesi taşımadığını da göstermektedir (Öztekin ve Öztekin, 2010: 537). Örnek olayda, çalışanın raporlu olduğu günde "herkese açık" olarak facebook adlı sosyal medya sitesinden gözetlendiğini bilerek paylaşım yapması mahremiyete yönelik tutumunu göstermekle birlikte yukarıda bahsedilen tezleri de doğrular niteliktedir.

Öte yandan, örnek olayda litaratürde "Facebook paylaşımı sebebiyle işten çıkarma" olarak kavramsallaştırılan olgunun işlendiği görülmektedir. İşyeri ve özel hayat arasındaki çizgiyi bulanık hale dönüştüren sosyal medya, çalışanların boş zamanlarında paylaşım yapabilecekleri önemli mecralardır. Ancak bu noktada, raporlu olunan günde fotoğraf paylaşılması durumuna parantez açmak gerekmektedir. Örnek olayda, çalışanın istirahat için rapor alıp deniz kenarında tatil yaptığını göstererek facebook da kendini ifşa etmesi işten çıkarmayla sonuçlanmaktadır.

\section{Örnek Olay 3}

Yargitay 9. Hukuk Dairesi

Esas Numaras1: 2016/22368

Karar Numarasi: 2017/14208

Karar Tarihi: 26.09.2017

Dava: İşe iade 
Olay: Mahkemece, davada ispat yükünün davalı üzerinde olduğu, davacının iş akdinin sosyal paylaşım sitesinde paylaştı̆̆l

- “...arkadaşlar patroncu bir IK personeli olacaksınız yapmayın o mesleği, çıldırtmayın insanı, bu kadar mı meraklısinız ...?”

- “...aaa pardon ben İK’yı insan kaynakları olarak biliyordum. Oysa ki siz patroncular işveren koruma departmanı yapmış onu.”

Şeklindeki paylaşımlardan dolayı feshedildiğini beyan etse de davalının paylaştı̆̆ı iddia edilen söz konusu

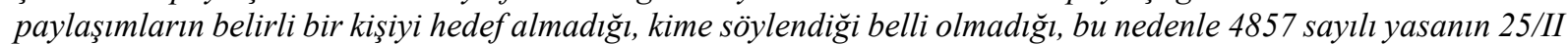
maddesinde belirtilen koşulları taşımadığından davalı feshinin yerinde olmadığı gerekçesiyle davanın kabulüne karar verilmiştir.

Yargıtay Kararı: Dosya içeriğine göre; davacının işsözleşmesinin işyeri ve çalışanları hakkında yaptığı sosyal medyadaki paylaşımlar üzerine haklı nedenle feshedildiği görülmüştür.

Davacı işçisinin kendisine ait twitter hesabından davalı işyerinde çalışan olduğu açıkça anlaşılmakla birlikte isim vermediği için kim/kimler olduğu belirlenemeyen başka çalışanlara hakaret ve sataşma niteliğinde birden fazla paylaşımda bulunduğu, örneğin “... arkadaşlar patroncu bir IK personeli olacaksanız yapmayın o mesleği, çıldırtmayın insanı, bu kadar mı meraklısınız ... şeklinde paylaşımlarının olduğu, isim zikretmese dahi çalıştığ işyerindeki başka bir çalışana açıkça hakaret ve sataşma niteliğinde twitter paylaşımlarının davalı işveren tarafından öğrenilmesi üzerine de davacı işçiden alınan savunmasında twitter paylaşımlarını kabul etmekle birlikte twitter hesabını takip edenler arasında işten arkadaşlarının bulunmadığl, dolayısıyla kastettiği kişi ya da kişilerin çalışma arkadaşları olmadığını beyan ettiği görülmüştür. Ancak atılan mesaj içeriğinden mesaja konu edilen kişi/kişilerin davacının çalışma arkadaşları oldukları, eksik olanın ise sadece somut kimlik bilgisi olduğu görülmektedir. Glyapta da olsa iş nedeniyle isim vermeksizin işyerindeki başka bir işyeri çallşanına hakaret ve sataşma niteliğindeki mesajlar nedeniyle işverence yapılan feshin haklı olduğu gözetilerek davanın reddi gerekirken kabulü hatalıdır.

(Kaynak: https://legalbank.net/belge/y-9-hd-e-2016-22368-k-2017-14208-t-26-09-

2017/3024953/sosyal+medya+fesih).

\section{Değerlendirme}

İşçinin işverene yahut onun ailesi üyelerinden birine yahut işverenin başka ișçisine sataşması haklı sebeple fesih oluşturmaktadır (İ̧KK, md. 25/2). Ahlak ve iyi niyet kurallarına uymayan haller ve benzerleri başlığı altında yer verilen bu durumda, sataşmanın işyerinde veya çalışma süreleri içinde olması gerekmemektedir (Sümer, 2018: 121). Üçüncü örnek olay, "sosyal medyada isim vermeden sataşma" durumunun haklı sebeple fesih oluşturabileceğini temsil etmesi bakımından önem arz etmektedir. İşçi sosyal medya paylaşımlarının ifade özgürlüğü kapsamında değerlendirilmesi gerektiğini ve belli bir kişiyi hedef almadığını beyan etse de doğrudan İK (insan kaynakları) personelini patroncu olarak nitelendirmesi sataşma kabul edilmektedir. Bu bakımdan bulgular, Thornthwaite (2013)'ün 'Social Media, Unfair Dismissal and the Regulation of Employees' Conduct Outside Work" adlı çalışmasının sonuçlarıyla benzerlik göstermektedir. Nitekim, çalışanların Facebook mecrasından çalışma arkadaşlarına ve yöneticilerine yönelik aşağılayıcı, saldırgan ve ayrımcı ifadeleri fesih sebebi oluşturacağı kimi araştırma sonuçlarıyla da desteklenmektedir (Thornthwaite, 2013).

Bir başka önemli nokta, “açıkça hakaret ve sataşma niteliğinde twitter paylaşımlarının davalı işveren tarafından öğrenilmesi üzerine” ifadesidir. İşçi hem gözetlemekte hem de gözetlendiğini bilerek paylaşım yapmaktadır. Bilgi teknolojilerindeki önemli gelişmelerle birlikte, gözetim çalışma hayatının dışına taşarak bireyin özel hayatını da kuşatmaktadır. Her an kayıt altına alınabilen dijital izler, bireylerin yaşamlarının her kesitinin denetlenmesini kolaylaştırmakta ve işverenlerin/iktidarın görmeden gözetleme arzusu gerçekleşmektedir. Gözetimin gönüllü biçimi bireyleri cezbetmekte ve gözetim bireysel rızaya dayalı sinoptikona doğru evrilmektedir (Okmeydan, 2017: 58-60). Ve böylece, bu büyülü sosyal medya platformları çalışanların mahremiyet endişesi taşımadan/gözetlendiğini bilerek paylaşım yapmalarını sağlayarak belli durumlarda disiplin uygulamalarıyla sonuçlanmaktadır.

İşten çıkarma olgusunu eleştirel insan kaynakları yönetimi yaklaşımıyla da açıklamak mümkündür. Bu anlayışının en önemli iddiası, İKY'nin etkisiz ve çıkarcı olduğudur (Gill, 2007). Keenoy’un 1990'larda söylediği meşhur 
“Koyun postuna bürünmüş kurt” ifadesi, İKY'nin katı gerçekliğini gizlemek adına yumuşak söylem kullanmasını açıklamaktadır (Legge, 1995; aktaran; Greenwood, 2002: 264). "Patroncu İK" söylemi, İK Y'nin işveren ve çalışan arasında kaldığı ikilemi göstermesinin yanında üstlendiği çıkarcı rolü betimlemesi bakımından önemli bir bulgudur.

\section{Örnek Olay 4}

Yargitay 9. Hukuk Dairesi

Esas Numaras1: 2017/27217

Karar Numaras1: 2018/13723

Karar Tarihi: 25.06.2018

Dava: Işe iade

Olay: ... davacının işe başladı̆̆ı tarihte yaptığı sözleşmeyi sosyal medya hesabında kölelik sözleşmesi olarak niteleyerek asll işverenin ismini kullanarak hem müvekkili şirketin hem de hizmet verilen proje sahibinin ticari itibarım zedelediğini, davacının raporlu olduğu tarihlerde sosyal medya hesabında gezdiği yerlere ait fotoğraf paylaştığını, davacının müvekkili şirketin asıl işvereninin talebi üzerine müvekkili şirketin merkez adresinde bulunan bir başka projede görevlendirildiğini ancak davacının bildirim yazısını imzalamaktan imtina ettiğini ve rapor bitiminden sonra işe başlamadığını, 26.01.2015 tarihli ihtarnamenin davacı tarafindan gönderildiğini ve bu ihtarname ile davacının kendisinin istifa ettiğini, müvekkili şirket tarafindan davacıya herhangi bir şekilde mobbing uygulanmadığını savunarak davanın reddini istemiştir.

Yargı Kararı: Somut uyuşmazlıkta davacının ... Projesinde müşteri temsilcisi/sosyal medya uzmanı olarak görev yaparken yazılı savunmasında da kabul ettiği üzere, işe giriş esnasında imzaladığ iş sözleşmesi için Facebook hesabında kurumsal müşteri olan ... 'in adını vererek "bugün yaptığım işs sözleşmesinde 46 sayfa okudum ve imzaladım. Artık köle olmaya hazırım” şeklinde paylaşımda bulunduğu, bu olayın... şirketi yetkilileri tarafından ögrenilmesi üzerine 12.01.2015 tarihinde şirketlerinin isminin bu şekilde sosyal medya üzerinde anılmasını istemediklerini belirterek davalı işverene bildirimde bulunulduğu, bu olay sebebiyle davalı işverenin yazll olarak uyarıldı̆̆ ve 16.01.2015 tarihinde yaşanan bu tatsı olay nedeniyle davacının ... Projesinde ... merkezi görevlisi görevlendirildiğinin bildirildiği ... davalı işverenin davacının projesinde çalıştı̆̆ firmayla imzaladı ̆̆ sözleşmeye yönelik "kölelik sözleşmesi" nitelemesini içeren sosyal medya paylaşımı ve ... firmasının yukarıda bahsedilen maili sonrasında davacıyla aynı projede çalışmaya devam etmek istememesi geçerli nedene dayanmakta olup davacının iş sözleşmesinin de müşteri temsilcisi olarak işe alındığı ve dinlenen tanık beyanlarından sosyal medya uzmanlı̆̆ında ... merkezlerine görevlendirmenin sıkça uygulanan bir değişiklik olduğu, davacı işçi tarafindan esaslı değişiklik mahiyetinde olmayan ve makul bir nedene dayanan bu görevlendirmenin kabul edilmemesi üzerine fesih işleminin geçerli olduğu anlaşılmakla davanın reddi gerekirken kabulüne karar verilmesi hatall olup bozma nedenidir.

(Kaynak: https://legalbank.net/belge/y-9-hd-e-2017-27217-k-2018-13723-t-25-06-2018/3186521/sosyal+medya + fesih).

\section{Değerlendirme}

İşveren işçinin çalışma koşullarındaki esaslı bir değişikliği ancak durumu işçiye yazılı olarak bildirmek suretiyle yapabilmektedir. İşçinin değişikliği belirlenen süre içinde yapmaması durumunda ise işveren feshin geçerli bir nedene dayandığını veya fesih için geçerli bir nedenin bulunduğunu yazılı olarak açıklamak suretiyle iş sözleşmesini sona erdirebilmektedir (İşK, m. 22). İşçinin esaslı değişiklik mahiyetinde olmayan görevlendirmeyi kabul etmemesi geçerli sebeple fesihle sonuçlanmaktadır.

İşçinin “bugün yaptığım iş sözleşmesinde 46 sayfa okudum ve imzaladım. Artık köle olmaya hazırım” şeklindeki paylaşımı olayın bir diğer yansımasıdır. Sosyal medyadan yapılan bu paylaşım, işverenin ticari niteliğini zedelemekte ve artık birlikte çalışılamayacağı konusunda önemli bir gerekçe olmaktadır. Örnek olayın bir başka vurgusu ise çalışanın raporlu olduğu günde fotoğraf paylaşmasına ilişkindir. Görüldügü üzere yakın zamanda insan kaynakları yöneticileri için böyle durumların değerlendirme unsuru olacağını söylemek yanlış olmaz. Bu noktada "abartılı paylaşım” kavramının da altınızı çizmek gerekmektedir. Bu yeni sıfat tamlaması, şahsi bilgileri ortaya serme, kişinin bir mecrada özel hayatını teşhir etmesi anlamlarına gelmektedir. "Bilmen ve bilinmek gerek" 
dürtüsüyle insanlar sosyal medyada kendilerini teşhir ederek dikizleme kültünün bir parçası haline dönüşmektedir (Niedzviecki, 2010: 8, 10-11). Giderek azalan mahremiyet kaygısı, çalışanların sonuçlarını düşünmeden sosyal medya paylaşımları yapmasına ortam hazırlamakta, bir tehdit olarak gözetim iş sözleşmelerinin sonlandırılmasında önemli rol oynamaktadır.

\section{TARTIŞMA VE SONUÇ}

İnsanların sosyal ve psikolojik doyum elde etme amacıyla gönüllü veri işçisi olarak rol aldıkları sosyal medya, insan kaynakları yönetimi açısından önemi giderek artan bir unsur haline gelmektedir. Panopticon'dan sinoptikon'a olan dönüşüm, çalışanları gözetimin gönüllü biçimine çekerken birtakım tuzakları da beraberinde getirmektedir. Performans, küçülme, davranış gibi çeşitli sebeplere dayanılarak yapılan işten çıkarma, abartılı paylaşım kültüründe yeni kılıflara bürünmektedir.

Bu çalışmada, "sosyal medya paylaşımları sebebiyle işten çıkarma" olgusu ele alınmaktadır. Çalışmanın ana amacı, çalışanların sosyal medya paylaşımlarının işten çıkarma sebebi oluşturup oluşturmayacağının incelenmesidir. Söz konusu probleme cevap aranan araştırmada, mahremiyete yönelik tutumların işten çıkarma yaptırımlarına olabilecek etkisi de sorgulanmaktadır. Nitel bir yaklaşımla belirlenen örnek olaylar "işten çıkarma ve sosyal medya" olgusunu inceleyen Yargitay kararlarına dayanmaktadır.

Araştırmada, çalışanların sosyal medya paylaşımları sebebiyle yapılan işten çıkarmalar dört örnek olay çerçevesinde incelenmiştir. Sosyal medya paylaşımına dayalı bu örnek olaylar mesai saatleri içinde çalışma disiplinini etkileyecek nitelikte fotoğraflar, raporlu olunan günde plajda tatil kıyafetleriyle çekilen fotoğraf, sosyal medyadan sataşma niteliğindeki mesajlar ve iş sözleşmesinin "kölelik sözleşmesi" olarak nitelendirilmesi olgularından meydana gelmektedir.

İlk örnek olay, mesai saatleri içinde fotoğraf paylaşılmasının hangi durumlarda çizgiyi aşacağını temsil etmesi bakımından önem arz etmektedir. Paylaşılan fotoğrafta kurumun “isim ve logosunun” yanında çalışanın formasının da olması davada dikkate alınan somut delillerdir. Binlerce kişi tarafından izlenebilecek bir ortamda yapılan bu paylaşım, işyerindeki çalışma disiplinini ve iş akışını etkileyecek nitelikte olması bakımından geçerli sebep olarak kabul edilmektedir. Mahremiyet açısından değerlendirildiğinde, çalışanın "hasta gelmesin diye dua ederken biz" ifadesini kullanarak sosyal medyadan kendini ifşa etmesi bilinme ve görünme isteğinin bir sonucu olarak görülebilmektedir.

İkinci örnek olay, çalışanın raporlu olduğu günde sosyal medyadan fotoğraf paylaşımı yapmasına ilişkindir. İstirahat raporu alınan dönemde çalışanın plajda tatil kıyafetleriyle çekilen fotoğraflarını sosyal medyadan paylaşması doğruluk ve bağlılığa aykırı kabul edilerek haklı sebeple fesih için yeterli görülmektedir. Çalışanın hem rapor alıp hem de tatil fotoğrafı paylaşması ahlak ve iyi niyet kurallarına aykırı bir eylem olarak değerlendirilmektedir. Gözetleyen, gözetlenen ve bundan keyif alan birey, mahremiyet kaygısı gütmeden kendini ifşa etmektedir.

Üçüncü örnek olayda, çalışanın sataşma niteliğindeki ifadelerini eleştirel insan kaynakları yaklaşımıyla açıklamak mümkündür. Doğrudan İKY'yi hedef alan "patroncu İK” şeklinde ifadeler ahlak ve iyi niyet kurallarına uymayan haller ve benzerleri unsuruna dayalı olarak haklı sebeple fesih gerekçesi oluşturmaktadır.

Görmeden gözetlenme arzusu, çalışanların sosyal medyada bıraktığı dijital ayak izleriyle daha kolay bir şekilde gerçekleşmektedir. Dördüncü örnek olayda, çalışanın imzaladığı sözleşmesini sosyal medya da "kölelik sözleşmesi” olarak nitelendirdiği abartılı paylaşımı, geçerli sebep olarak fesih gerekçesi oluşturmaktadır.

Geçerli sebeple yapılan fesihlerde öne çıkan olgu, yapılan sosyal medya paylaşımı sonucunda artık işçi ve işverenin birlikte çalışmaya devam etmesinin beklenemeyeceğidir. Haklı sebeplere dayanarak yapılan fesihlerde ise, ahlak ve iyi niyet kurallarına uymayan haller ve benzeri durumların gerekçe olduğu sonucuna varılmaktadır. İş yerinden sosyal medya paylaşımı yapılması iş disiplinini bozması bakımından geçerli sebep teşkil ederken, çalışanın hem istirahat raporu alıp hem de deniz kıyısından fotoğraf paylaşması doğrululuk ve bağlılığa uymaması bakımından haklı sebep oluşturmaktadır. Her iki örnek olayda da mahremiyete yönelik benzer tutum içinde olarak ifşa davranışı sergileyen çalışanlar olmasına rağmen fotoğrafın çekildiği durum ve şartlara göre feshin gerekçesinin değiştiği görülmektedir. Çalışanların sosyal medya platformlarında işverene/kuruma yönelik eleştirel paylaşımları sataşma niteliği taşıması durumunda işverenin haklı sebeple fesih yapabilmesine imkân vermektedir. 
Çalışmanın sonucunda, çalışanların mahremiyeti göz ardı ederek sosyal medya platformlarında yaptıkları paylaşımların işten çıkarma sebebi olabileceği ortaya çıkmıştır. Dolayısıyla, modernleşme sürecinde mahremiyete yönelik tehditler olarak sosyal medyada ifşa ve gözetimin işten çıkarma kararlarının verilmesinde önümüzdeki dönemlerde çok önemli gerekçeler olacağını söylemek mümkündür. Nitekim bu çalışmada elde edilen sonuçların literatürde sosyal medya sebebiyle işten çıkarma olgusunu inceleyen çeşitli çalışmalarla benzerlik gösterdiği ve onları desteklendiği görülmektedir (Thornthwaite, 2013; Hidy ve McDonald, 2013). Pen'in çalışmasında bir kuaförün Facebook sayfasında işvereniyle alay ettiği paylaşımı ilgili haksız işten çıkarma sayılmıştır. Yorumların sadece çalışanın arkadaşlarına açık olması, işverenin kuaför salonuna zararının az olması ve paylaşımın bir hafta içinde silinmesi unsurları göz önünde bulundurulmuştur (Pen, 2016: 272). Geçerli sebeple fesih ile sonuçlanan ilk örnek olayda, paylaşımın 1285 kişi tarafından beğenilmesinin ve fotoğrafın altına 52 adet yorum yapılmasının davanın seyri için göze çarpan bir nitelik oluşturduğu ifade edilmişti. Dolayısıyla sosyal medya sebebiyle yapılan işten çıkarmalarda söz konusu paylaşımları kimlerin ve kaç kişinin gördüğü davanın sonucu açısından önem taşımaktadır. O’Brien (2013) ise Facebook paylaşımı sebebiyle işten çıkarılmayı örneklerle incelediği çalışmasında yine benzer şekilde bir çalışanın çalıştığı kurumun müşterilerine ve işine yönelik küfür içeren sosyal medya paylaşımını değerlendirmektedir. Çalışanın Facebook sayfasında iş arkadaşlarının da olması ve gizlilik ayarlarının herkese açık şekilde bulunmasına dikkat çekilmektedir. Bu çalışmanın da problemi bağlamında bakıldığında, çalışanın sosyal medya platformlarında kendini ifşa etmesi ya da gözetim mekanizmasından kaçamaması işten çıkarma uygulamalarında önem arz etmektedir (O’Brien, 2013: 346).

Çalışmanın en önemli katkısı, sosyal medya sebebiyle işten çıkarma olgusunu mahremiyete yönelik modern tehditler olan ifşa ve gözetim bağlamında incelemesidir. Sadece işyerinde mesai saatleri içinde çalışanlar tarafından yapılan sosyal medya paylaşımları değil iş dışında sosyal medyada yapılan paylaşımların da iş sözleşmelerini etkileyebileceğini dolayısıyla işten çıkarma yapılabileceğini tartışma zemine çekmek İKY alanına önemli katkılar sunmaktadır. Bireylerin kimi zaman göz önünde olma kimi zamanda beğenilme arzusuyla sosyal medyada kendilerini fotoğraflarla ifşa etmelerinin işten çıkarma sebebi olarak göz önünde bulundurulması çalışma hayatı adına önem taşımaktadır. Bir başka tartışma konusuysa sosyal medyanın işverenlerin yeni gözetim aracı haline gelmesi durumudur. Öyle ki artık sosyal medya sadece işe alımda değil işten çıkarmada da işverenler için değerlendirme unsuru haline dönüşmüştür.

Bu çalışmayla, çalışanların sosyal medya paylaşımlarının işten çıkarma ve çalışma ilişkileri kapsamında insan kaynakları yönetimi alanı için önemi ortaya koyulmaya çalışılmıştır. Çalışmanın en önemli sınırlılığı ikincil verilere dayanan örnek olaylarla durum tespiti yapılması ancak çalışanların ya da işverenlerin görüşlerinin eksik kalmasıdır. Sonraki çalışmalarda yapılacak bir mülakatla konunun daha derinlemesine incelenmesi faydalı olacaktır. Tüm bunlarla birlikte, çalışmanın hem araştırmacılar hem de iş hayatı için işten çıkarma ve sosyal medya olguları konusunda yol gösterdiği/farkındalık oluşturduğu ümit edilmektedir.

\section{KAYNAKÇA}

4857 sayılı İş Kanunu, Erişim adresi: https://kms.kaysis.gov.tr/Home/Goster/34576, (26 Mart 2019).

6098 sayılı Türk Borçlar Kanunu, Erişim adresi: http://www.mevzuat.gov.tr/MevzuatMetin/1.5.6098.pdf, (26 Mart 2019).

7036 sayılı İş Mahkemeleri Kanunu, Erişim adresi: https://www.mevzuat.gov.tr/MevzuatMetin/1.5.7036.pdf, (26 Mart 2019).

Abril, P. S., Levin, A. ve Riego, A. D. (2012). Blurred boundaries: Social media privacy and the twenty-firstcentury employee. American Business Law Journal, 49(1), 63-124.

Akyiğit, E. (2013). İş hukuku. (9.bs). Ankara: Seçkin Yayıncılık.

Alaca, E. ve Yılmaz, B. (2016). Bilgi ve iletişim teknolojilerinin kullanımı ve bilgi toplumuna dönüşüm: Türkiye'de durum. Türk Kütüphaneciliği, 30 (3), 507-523.

Altman, I. (1977). Privacy regulation: Culturally universal or culturally specific?. Journal of Social Issues, 33, 6684. 
Armstrong, M. ve Taylor, S. (2014). Armstrong's handbook of human resource management practice. UK: Kogan Page.

Baybora, D. (2017). Yargı kararları ile sosyal medyada konuşmanın iş sözleşmesine etkisi. İSGHD, 14(56), 17051740 .

Berg, B. L. ve Lune, H. (2015). Sosyal bilimlerde nitel araştırma yöntemleri. H. Aydın (Çev.), Konya: Eğitim Kitabevi.

Bezci, B. (2015). Kamusallığg akıcı kılan ama temsiliyeti buharlaştıran bir sorun olarak sosyal medya. Ö. Oğuzhan (Ed.), Illetişimde sosyal medya sosyal medyada etkileşim içinde (29-36), İstanbul: Kalkedon Yayınları.

Bozkurt, F. G. ve Triki, M. (2016). Bir kurum olarak sosyal medyanın insan kaynakları yöneticilerinin iş gören tedarik-seçim ve işe alma kararları üzerindeki etkisi: Tunus örneği. Çukurova Üniversitesi İktisadi ve Ídari Bilimler Fakültesi Dergisi, 20(1), 89-107.

Bozkurt, V. (2005). Endüstriyel \& Post-endüstriyel dönüşüm. İstanbul: Aktüel Yayınları.

Brown, M. ve Dent, C. (2017). Privacy concerns over employer access to employee social media. Monash University Law Review, 43(3), 796-827.

Bucher, T. (2015). Networking or what the social means in social media. Social Media+ Society, 1(1), 1-2.

Castells, M. (2005). Enformasyon çă̆l: ekonomi, toplum ve kültür-birinci cilt: Ăg toplumunun yükselişi. E. Kılıç (Çev.), İstanbul: İstanbul Bilgi Üniversitesi Yayınları.

Çelik, A. (1998). Bilgi toplumu üzerine bazı notlar. Hacettepe Üniversitesi Edebiyat Fakültesi Dergisi, 15(1), 5359.

Çelik, N., Canikoğlu, N. ve Canbolat, T. (2018). İş hukuku dersleri. İstanbul: Beta Basım.

Çetin, C., Arslan, M. L. ve Dinç, E. (2015). İnsan kaynaklart yönetimi. İstanbul: Beta Basım.

DeCenzo, D. A., Robbin, S. P. ve Verhulst, S. L. (2017). İnsan kaynakları yönetiminin temelleri. C. Çetin ve L. Arslan (Çev.), Ankara: Nobel Yayıncılık.

Dellaloğlu, B. F. (2015). Mesafeli yakınlık: Facebook ve Twitter çağının yeni toplumsallığı. Ö. Oğuzhan (Ed.), İletişimde Sosyal Medya Sosyal Medyada Etkileşim kitabı içinde (21-27). İstanbul: Kalkedon Yayınları.

Dessler, G. (2000). Human resource management. New Jersey: Prentice Hall.

Dulay, D. (2010). İş sözleşmesinin performansa dayalı olarak feshedilmesi. Legal İş Hukuku ve Sosyal Güvenlik Hukuku Dergisi, 7 (27), 963-978.

Foucault, M. (2006). Hapishanenin doğuşu. M. A. Kılıçbay (Çev.), Ankara: İmge Kitabevi.

Giddens, A. (1997). Sociology (3rd edition). UK: Polity Press.

Gill, C. (2007). A review of the critical perspective on human resource management. MBS Working Paper, 1-12.

Global Digital Report 2019. (2019). Erişim adresi: www.wearesocial.com, (2 Mart 2019).

Greenwood, M. R. (2002). Ethics and hrm: a review and conceptual analysis. Journal of Business Ethics, 36, 261278.

Hegel, W. G. F. (2010). Karalama defterlerinden aforizmalar. E. Orman ( Çev.), İstanbul: Belge Yayınları.

Hermida, A. (2017). Herkese söyle: Sosyal medya'da neden paylaşımda bulunuruz. A. A. Sabancı, (Çev.), İstanbul: Kafka.

Hidy, K. M. ve McDonald, M. S. E. (2013). Risky business: The legal implications of social media's increasing role in employment decisions. Journal of Legal Studies in Business, 18, 69-88.

Holvast J. (2008). History of Privacy. In: Matyáš V., Fischer-Hübner S., Cvrček D., Švenda P. (Ed.), The Future of Identity in the Information Society. Privacy and Identity 2008. IFIP Advances in Information and Communication Technology, 298. Berlin, Heidelberg: Springer. 
https://legalbank.net/belge/y-7-hd-e-2015-46017-k-2016-11591-t-26-05-2016-ise-iade-istemi-calisma-saatleriicerisinde-arkadaslar/2610486, (26 Mart 2019).

https://legalbank.net/belge/y-9-hd-e-2016-17532-k-2017-12196-t-06-072017/2881519/06+07+2017++2016_17532+2017_12196, (26 Mart 2019).

https://legalbank.net/belge/y-9-hd-e-2016-22368-k-2017-14208-t-26-09-2017/3024953/sosyal+medya+fesih, (26 Mart 2019).

https://legalbank.net/belge/y-9-hd-e-2017-27217-k-2018-13723-t-25-06-2018/3186521/sosyal+medya+fesih, (26 Mart 2019).

Katz, E. (1959). Mass communications research and the study of popular culture: An editorial note on a possible future for this journal, Departmental Papers (ASC), 165.

Keser, H. (2019). İşçi davranışları kapsamında işçinin talimatlara aykırı bilgisayar, internet ve cep telefonu kullanımı sebebi ile iş sözleşmesinin işverence feshedilmesi. ISGHD, 16(62), 445-490.

Kutsal, B. S. ve Kolan, Ş. (2019). Paylaşmadan önce dikkat! İşçileri işyeri dışında sosyal medya kullanımları üzerine hukuki bir değerlendirme. ISSGH, 16(62), 491- 562.

Losyk, B. (2006). Sakin ol sinirlerine hâkim ol. İstanbul: MESS Yayınları.

McGinley, A. C. ve McGinley-Stempel, R. P. (2012). Beyond the water cooler: Speech and the workplace in an era of social media. Hofstra Labor \& Employment Law Journal, 30(70), 75-119.

Merriam, S. B. (2013). Nitel verilerin analizi. S. Turan (Ed.), Nitel araştırma: Desen ve uygulama için bir rehber içinde (161-198), Ankara: Nobel Yayın.

Mooney, C. (2015). Online privacy and social media. USA: ReferencePoint Press.

Newell, P. B. (1995). Perspectives on privacy. Journal Of Environmental Psychology, 15 (2), 87-104.

Niedzviecki, H. (2010). Dikizleme günlüğ̈̈: Kendimizi ve komşularımızı gözetlemeyi niçin bu kadar sevdik? G. Gündüç (Çev.), İstanbul: Ayrıntı Yayınları.

O’Brien, C. N. (2013). The top ten nlrb cases on facebook firings and employer social media policies. Oregon Law Review, 92, 346-380.

Okmeydan, S. B. (2017). Postmodern kültürde gözetim toplumunun dönüşümü: 'Panoptikon'dan 'sinoptikon’ ve 'omniptikon'a”. Online Academic Journal of Information Technology, 8(10). 45-69.

Önkal, G. ve Gündüzlü, E. (2015). Teknoloji düşün(e)mez: sosyal medyada ihtiyaçlar-değerler çatışmasının felsefi analizi. Ö. Oğuzhan (Ed.), İletişimde sosyal medya sosyal medyada etkileşim içinde (37-51). İstanbul: Kalkedon Yayınları.

Özdemir, Y. (2017). İşe alım: Süreç, kavram, uygulama. Sakarya: Sakarya Yayıncılık.

Öztekin, H. ve Öztekin, A. (2010). Modernleşme-mahremiyet ilişkisi ve siber mekânda mahremiyetin aleniyete dönüşmesi. E-Journal of New World Sciences Academy Humanities, 5(4), 526-540.

Pen, J. (2016). Never tweet? : Social media and unfair dismissal. Alternative Law Journal, 41(14), 271-274.

Peppercorn, S. (2018). How to silence your inner critic after a layoff. Harvard Business Review, 2-5. https://hbr.org/2018/07/how-to-silence-your-inner-critic-after-a-layoff.

Sabuncuoğlu, Z. ve Tüz, M. (2003). Örgütsel psikoloji. Bursa: Furkan Ofset.

Selvi, Ö. G. Ö. (2012). Bilgi toplumu, bilgi yönetimi ve halkla ilişkiler. Gümüşhane Üniversitesi İletişim Fakültesi Elektronik Dergisi, 1(3).

Silah, M. (2001). Çalışma psikolojisi. Ankara: Selim Kitabevi. 
Stone, E. F., Gueutal, H. G., Gardner, D. G., ve McClure, S. (1983). A field experiment comparing informationprivacy values, beliefs, and attitudes across several types of organizations. Journal of Applied Psychology, 68(3), 459-468.

Sümer, H. H. (2018). İş hukuku. Ankara: Seçkin Yayıncılık.

Şener, G. ve Kuş, O. (2015). Büyük biraderden büyük veriye gözetim toplumu. Ö. Oğuzhan (Ed.), Illetişimde sosyal medya sosyal medyada etkileşim kitabı içinde (53-82). İstanbul: Kalkedon Yayınları.

Şimşek, T. (2019). Sosyal medyada mahremiyetin ifşası "İnstagram örneği'”. Sosyolojik Düşün, 4(1), 10-24.

Tartanoğlu, Ş. (2012). Örgütlerde denetim ve gözetim. M. Zencirkıran (Ed.), Örgüt Sosyolojisi içinde (233-263). Bursa: Dora Basım Yayın.

Tatl1, O. (2016). Zehirli sarmaşık Facebook: İletişim, algl ve propaganda. İstanbul: Maşuk Kitap.

TDK, Genel Türkçe Sözlük, Mahremiyet.

TDK. (2019). Mahremiyet. Erişim adresi: http://www.tdk.gov.tr (1 Mart 2019).

Thornthwaite, L. (2013). Social media, unfair dismissal and the regulation of employees' conduct. Australian Journal of Labour Law, 1-21.

Vardarlıer, P. (2018). Sosyal medyanın insan kaynakları yönetimindeki rolü. H. Yıldız (Ed.), Sosyal medyanın iş yaşamındaki yeri içinde (91-112). İstanbul: Beta Basım.

Waters, S. ve Ackerman, J. (2011). Exploring privacy management on Facebook: Motivations and perceived consequences of voluntary disclosure. Journal of Computer-Mediate Communication, 17 (1), 101-115.

Weller, K., Burns, A., Burgess, J., Mahrt, M. ve Puschmann, C. (2016). Twitter ve toplum. İstanbul: Epsilon Yayıncilik.

Westin, A.F. (2003). Social and political dimensions of privacy. Journal of Social Issues, 59, 431-453.

Yaylagül, L. (2014). Kitle iletişim kuramları: Egemen ve eleştirel yaklaşımlar. Ankara: Dipnot Yayınları.

Yıldırım, A. ve Şimşek, H. (1999). Nitel araştırma yöntemleri. Ankara: Seçkin Yayınevi.

Yüksel, M. (2003). Mahremiyet hakkı ve sosyo-tarihsel gelişimi. Ankara Üniversitesi SBF Dergisi, 58(1). 181213. 